\title{
Halomonas organivorans sp. nov., a moderate halophile able to degrade aromatic compounds
}

Correspondence

Antonio Ventosa

ventosa@us.es

\author{
María Teresa García, Encarnación Mellado, Juan Carlos Ostos \\ and Antonio Ventosa
}

Department of Microbiology and Parasitology, Faculty of Pharmacy, University of Seville, Seville, Spain

\begin{abstract}
A group of moderately halophilic bacteria able to degrade aromatic organic compounds contaminating hypersaline habitats in southern Spain have been isolated and characterized. The taxonomic position of these strains was determined using phenotypic, phylogenetic and genotypic methods. The $\mathrm{G}+\mathrm{C}$ content of their DNA ranged from $61 \cdot 0$ to $62 \cdot 9 \mathrm{~mol} \%$. DNA-DNA hybridization studies showed that they constitute a genospecies, having DNA-DNA hybridization values of $90-100 \%$. Analysis of the complete $16 \mathrm{~S}$ rRNA gene sequence revealed a high level of similarity with members of the genus Halomonas, sharing $98 \% 16 \mathrm{~S}$ rRNA gene sequence similarity with the type strains of Halomonas salina and Halomonas halophila. However, phenotypic differences and the low level of DNA-DNA hybridization suggest the placement of these strains as a novel species within the genus Halomonas. The name Halomonas organivorans sp. nov. is proposed, with strain $\mathrm{G}-16.1^{\top}$ (=CECT $5995^{\top}=$ CCM $7142^{\top}$ ) as the type strain. This novel species of Halomonas is characterized by its ability to use a wide range of organic compounds (benzoic acid, $p$-hydroxybenzoic acid, cinnamic acid, salicylic acid, phenylacetic acid, phenylpropionic acid, phenol, $p$-coumaric acid, ferulic acid and $p$-aminosalicylic acid), and it could be useful for the decontamination of polluted saline habitats.
\end{abstract}

The two main groups of micro-organisms adapted for life in hypersaline environments are extremely halophilic archaea and moderately halophilic bacteria. Moderately halophilic bacteria constitute a group able to grow in a wide range of saline environments. Several studies on their molecular adaptation to media with different salt concentrations have increased the scientific interest in these bacteria (Nieto \& Vargas, 2002). Moreover, extremophiles in this group exhibit great potential for biotechnological exploitation: in fact, these bacteria have been used as a source of compatible solutes or hydrolytic enzymes (Mellado \& Ventosa, 2003).

Saline and hypersaline environments are often contaminated with organic compounds as a result of industrial activities and urban water effluents. Although the use of different bacterial groups in bioremediation processes has been widely studied, the ability of native communities of halophilic bacteria to be used for the degradation of pollutants in saline habitats has not been studied in a systematic way, and only a few studies have reported the biotechnological potential of this group of extremophiles

Published online ahead of print on 12 March 2004 as DOI 10.1099/ ijs.0.63114-0.

The GenBank/EMBL/DDBJ accession number for the 16S rRNA gene sequence of strain $\mathrm{G}-16.1^{\top}$ is AJ616910. in the decontamination of saline environments (Margesin \& Schinner, 2001; Mellado \& Ventosa, 2003). Thus, the identification of moderate halophiles that play an important role in the degradation of pollutant compounds is of great interest in the context of assessing acceleration of the environmental repair process for bioremediation in contaminated saline habitats.

Recently, we have focused on the characterization of the moderately halophilic bacterial community able to degrade different aromatic pollutants in saline habitats of southern Spain, the primary goal being the isolation of potential degraders able to grow at different salinities. In the course of this work, four novel bacterial strains, designated G$16.1^{\mathrm{T}}, \mathrm{G}-2.5, \mathrm{G}-17.1$ and $\mathrm{H}-30.2$, were isolated from saline soils in Isla Cristina (Huelva), Spain. These bacteria were isolated because of their ability to grow in phenol (strains G-16.1 ${ }^{\mathrm{T}}, \mathrm{G}-2.5, \mathrm{G}-17.1$ ) or $p$-coumaric acid (strain H-30.2) as the sole source of carbon and energy. For this purpose, an enrichment culture using sterile mineral medium M63 (Cohen \& Rickenberg, 1956) supplemented with $10 \%$ $\mathrm{NaCl}$ was used. Phenol or $p$-coumaric acid was added to the mineral medium at a concentration of $0.05 \%(\mathrm{w} / \mathrm{v})$. After three enrichment steps, the cultures obtained were plated on $\mathrm{M} 63+10 \% \mathrm{NaCl}$ medium supplemented with the organic compound and incubated at $37^{\circ} \mathrm{C}$. Colonies that differed in appearance from each other were picked and 
inoculated into the liquid selective medium previously described. Of the isolates, four strains showing a high level of degradative activity were selected for further studies.

To study the ability of the isolates to degrade a variety of aromatic compounds, substrates were added to the saline minimal medium $\mathrm{M} 63+10 \% \mathrm{NaCl}$ at different concentrations $(0.05 \%$ for phenol and $p$-coumaric acid and $1-5 \mathrm{mM}$ for the other substrates). This medium was inoculated with strains G-16.1 ${ }^{\mathrm{T}}, \mathrm{G}-2.5$, G-17.1 and H-30.2, and the utilization of these compounds was tested by monitoring the increase in turbidity. This group of isolates utilized, in addition to phenol and p-coumaric acid, a diverse range of compounds as sole carbon and energy sources (Table 1), indicating that they constitute promising potential degraders in bioremediation processes. The aim of this work was to study these four isolates in detail by using a polyphasic taxonomic approach.

A preliminary taxonomic study based on the determination and comparison of partial sequences of 16S rRNA genes placed these bacterial isolates in the genus Halomonas. This genus - currently one of the largest among the moderate halophiles - was originally proposed by Vreeland et al. (1980) with a single species, Halomonas elongata. Currently, the genus comprises more than 20 species, including bacterial isolates from different terrestrial and aquatic environments with, in most cases, high salt concentrations. This genus has been considered as a model system among the moderate halophiles and has been used extensively for studies concerning both osmoregulatory mechanisms and physiological adaptations (Ventosa et al., 1998; Nieto et al., 2000). On the other hand, the genus Halomonas is a taxon comprising strains that are metabolically versatile: some Halomonas species have been described as denitrifying halophilic bacteria useful in the reduction of nitrate during the treatment of saline waste (Berendes et al., 1996; Mormile et al., 1999; Romano et al., 1996; Dobson \& Franzmann, 1996). In addition, there are also a few reports on Halomonas strains able to degrade aromatic pollutants (Maltseva et al., 1996; Muñoz et al., 2001).

Table 1. Ability of strains of $H$. organivorans sp. nov. to use a variety of aromatic substrates as sole carbon and energy sources

All strains were able to grow on phenylacetic acid, phenol, $p$-coumaric acid and ferulic acid. Symbols: +, growth; -, no growth.

\begin{tabular}{|lcccc|}
\hline Aromatic compound & G-16.1 & G-2.5 & G-17.1 & H-30.2 \\
\hline Benzoic acid & + & - & + & + \\
p-Hydroxybenzoic acid & + & - & + & + \\
Cinnamic acid & + & + & - & + \\
Salicylic acid & + & + & + & - \\
Phenylpropionic acid & + & + & + & - \\
p-Aminosalicylic acid & + & - & + & - \\
\hline
\end{tabular}

The isolates were cultured on a complex medium (SW-10) containing $10 \%$ salts supplemented with $0.5 \%(\mathrm{w} / \mathrm{v})$ yeast extract (Ventosa et al., 1982). The strains were routinely grown at 200 r.p.m. in an orbital shaker (New Brunswick Scientific) at $37^{\circ} \mathrm{C}$. When necessary, solid medium was

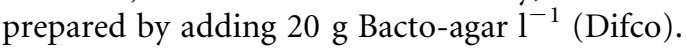

The methods used for phenotypic characterization have been described previously in detail (Ventosa et al., 1982; Quesada et al., 1984; García et al., 1987). Isolates G-16.1 ${ }^{\mathrm{T}}$, G-2.5, G-17.1 and H-30.2 were Gram-negative rods that were oxidase-negative, catalase-positive and strictly aerobic. On SW-10 medium incubated at $37^{\circ} \mathrm{C}$, the strains produced circular colonies, each $2-3 \mathrm{~mm}$ in diameter. Colonies were flat/slightly convex with irregular edges.

The salt requirement of these strains was determined in complex medium SW at different salt concentrations. The isolates grew in a wide range of salinities (from 1.5 to $30 \%$, $\mathrm{w} / \mathrm{v}$, salt), producing optimal growth in media containing $7 \cdot 5-10 \%(\mathrm{w} / \mathrm{v})$ salt. They did not grow in the absence of $\mathrm{NaCl}$. These results indicated that the four isolates were strictly halophilic and could be assigned to the group of moderately halophilic bacteria (Kushner \& Kamekura, 1988). Some other physiological characteristics of the strains are shown in Table 2 and in the species description.

Nutritional features of the isolates were determined using GN MicroPlates (Biolog). Strains were grown on isolate medium (Biolog) at $37^{\circ} \mathrm{C}$ for $24 \mathrm{~h}$. Suspensions of the strains were made using prewarmed sterile saline medium $(3 \% \mathrm{NaCl})$, within the density range specified by the manufacturer. Immediately after suspension of the cells in the saline solution, the suspensions were transferred into sterile multichannel pipetter reservoirs (Biolog). Biolog GN MicroPlates were inoculated with $125 \mu \mathrm{l}$ cell suspension per well by means of an eight-channel repeating pipetter (Biolog). The inoculated Biolog GN MicroPlates were incubated at $37^{\circ} \mathrm{C}$ for $24 \mathrm{~h}$ and the results were read with a MicroPlate Reader, using Microlog 3.59 computer software to perform automated reading. The results of the nutritional tests are shown in the description of the species. The four isolates show a greater nutritional versatility than other related Halomonas species.

Chromosomal DNA from the four strains was isolated and purified according to the methods described by Wilson (1987) and Marmur (1961). The 16S rRNA genes of the four isolates were amplified by a PCR using two universal primers, as described previously (Mellado et al., 1995), and almost-complete nucleotide sequences (approx. $1450 \mathrm{bp}$ ) were determined. The ARB software package (Ludwig \& Strunk, 1996) was used for $16 \mathrm{~S}$ rRNA gene sequence analysis.

16S rRNA gene phylogenetic analysis performed on the basis of the neighbour-joining method (Saitou \& Nei, 1987) clearly showed the position of this group of strains within the family Halomonadaceae, in the genus Halomonas. 
Table 2. Differential phenotypic characteristics of $H$. organivorans sp. nov. and other related species of the genus $H a l o m o n a s$ Data are from Arahal et al. (2002), Mata et al. (2002), Vreeland et al. (1980) and this study. +, Positive; -, negative; ND, not determined.

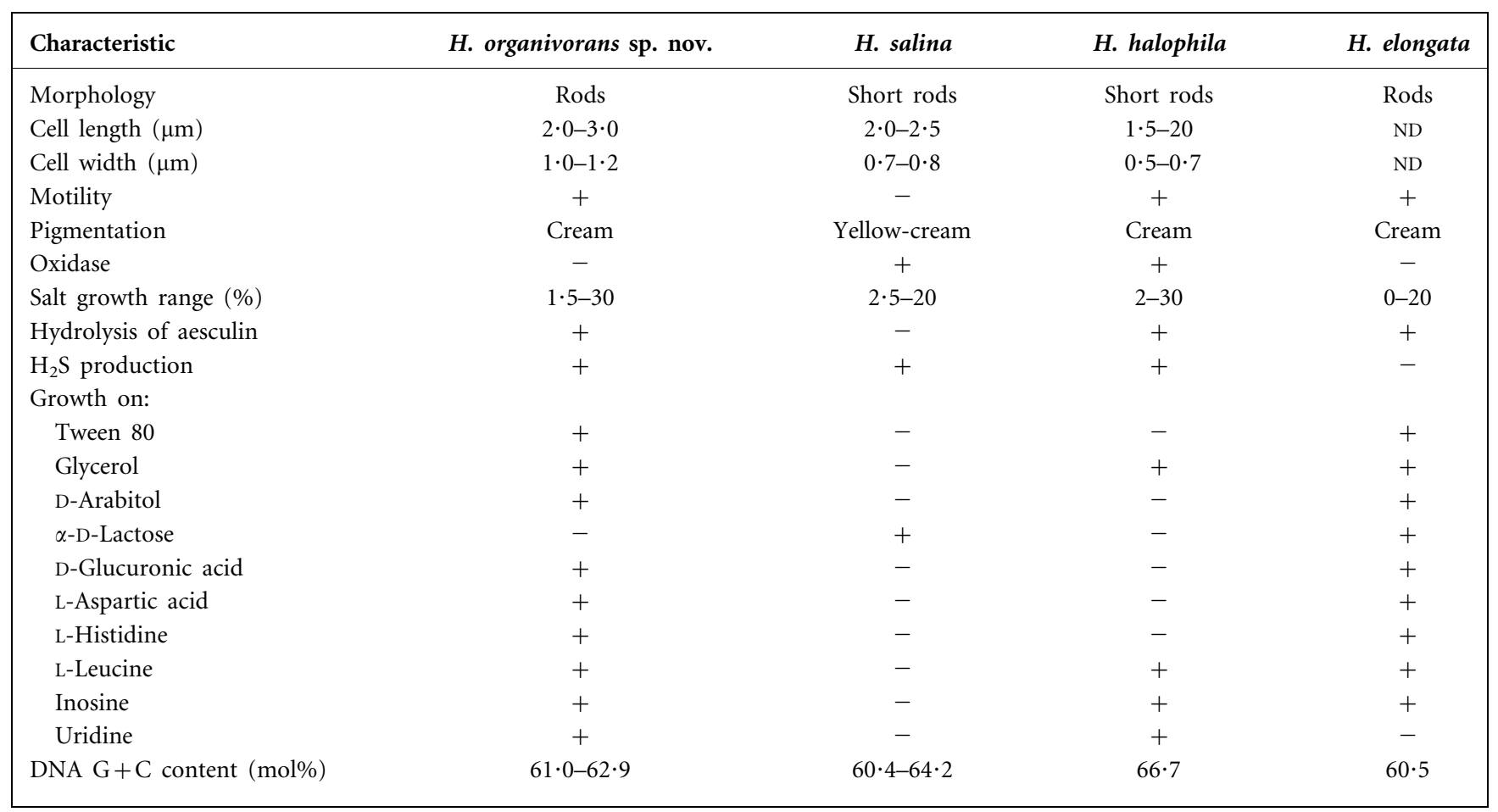

Maximum-parsimony- and maximum-likelihood-based trees using the full dataset or a selection of sequences were also obtained which showed the same phylogenetic position of the group of isolates, i.e. in the genus Halomonas, grouped together and forming a cluster separate from the other species (Fig. 1). Base-frequency filters were applied in the sequence comparison analysis and the effects on the results were evaluated.

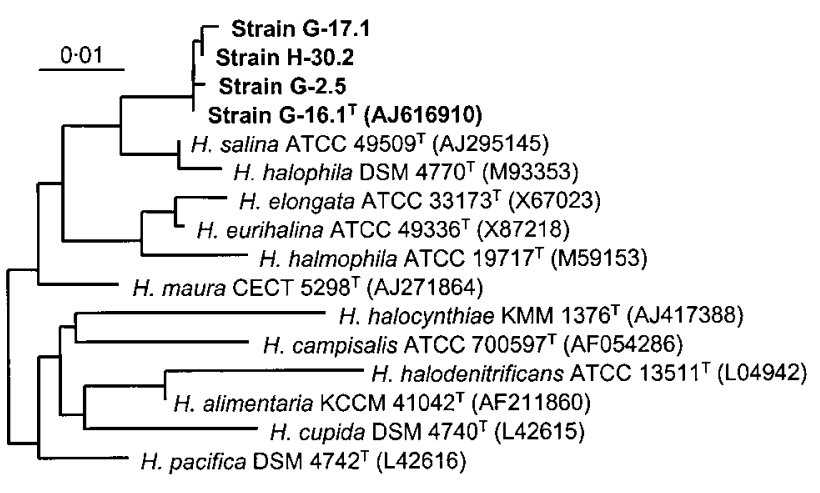

Fig. 1. Phylogenetic tree, based on 16S rRNA gene sequences, showing the position of the novel group of four isolates with respect to other Halomonas species. The tree was obtained using the maximum-likelihood method. GenBank/ EMBL/DDBJ accession numbers are given in parentheses. Bar, $1 \%$ sequence divergence.
The $16 \mathrm{~S}$ rRNA gene sequence of strain G-16.1 ${ }^{\mathrm{T}}$ was very similar to those of strains G-2.5, G-17.1 and H-30.2, with sequence similarities of $99 \cdot 8,99 \cdot 7$ and $99 \cdot 9 \%$, respectively. All four strains are on the same phylogenetic branch and their 16S rRNA gene sequences contain the four signature nucleotides that define the genus Halomonas as well as the 15 signature nucleotides characteristics of the family Halomonadaceae, as described by Dobson \& Franzmann (1996).

The similarities between the 16S rRNA gene nucleotide sequences of the isolates and those of the other 25 currently accepted Halomonas species were between 93 and $98 \%$. The highest similarity values between the sequence of strain G-16.1 $1^{\mathrm{T}}$ and those of the type strains of species of the genus were for Halomonas salina $(98.0 \%)$ and Halomonas halophila $(98 \cdot 0 \%)$. These two species have 99.0\% $16 \mathrm{~S}$ rRNA gene sequence similarity but are considered different species on the basis of other phenotypic and genotypic data (Valderrama et al., 1991).

Recently, Arahal et al. (2002) performed a phylogenetic analysis of the genus Halomonas based on 23S and 16S rRNA gene sequence comparisons: two clear phylogenetic groups were observed. Group 1 comprises the type species of Halomonas, H. elongata and four other species, Halomonas eurihalina, Halomonas halmophila, $H$. halophila and $H$. salina. Since the publication of this work, a number of novel species belonging to the genus Halomonas have been described, and our phylogenetic analysis based on the 
sequence of $16 \mathrm{~S}$ rRNA genes reveals that Halomonas maura could also be included in group 1 . The phylogenetic analyses performed also show that strains G-16.1 ${ }^{\mathrm{T}}$, G-2.5, G-17.1 and H-30.2 cluster with species belonging to the abovementioned Halomonas group 1 (Fig. 1) and show clearly that they are members of the Halomonas 'sensu stricto group'.

The $\mathrm{G}+\mathrm{C}$ content of genomic DNA was determined by the method of Marmur \& Doty (1962) using the equation of Owen \& Hill (1979): the values for our isolates ranged between 61.0 and $62.9 \mathrm{~mol} \%$. These values fall within the range described for species of the genus Halomonas (5268 mol\%; Franzmann et al., 1988). However, the G+C content is lower than those of the most phylogenetically related species $(64 \cdot 2 \mathrm{~mol} \%$ for $H$. salina, $66 \cdot 7 \mathrm{~mol} \%$ for H. halophila).

To define the taxonomic position of the novel isolates able to degrade different organic pollutants, DNA-DNA hybridization studies were carried out according to the competition procedure of Johnson (1994), described in detail in Mormile et al. (1999). The hybridization temperature was $57^{\circ} \mathrm{C}$, which is within the limit of validity for the filter method (De Ley \& Tijtgat, 1970), and the percentage of hybridization was calculated according to Johnson (1994). The values obtained in the DNA-DNA hybridization studies between strain G-16.1 ${ }^{\mathrm{T}}$ and the type strains of the Halomonas species with which it formed a phylogenetically coherent cluster are shown in Table 3. The DNA-DNA hybridization between strain G-16.1 ${ }^{\mathrm{T}}$ and isolates G-2.5, G-17.1 and H-30.2 was equal to, or greater than, $90 \%$, confirming the phylogenetic data and the phenotypic characteristics shared by this group of strains. On the other hand, DNA-DNA hybridization between strain G$16.1^{\mathrm{T}}$ and closely related species of the genus Halomonas was significantly below $70 \%$, showing relatedness values of

Table 3. DNA $G+C$ content and levels of DNA-DNA hybridization between the novel isolates and some phylogenetically related species of the genus Halomonas

Data are from this study and from Valderrama et al. (1991) unless indicated.

\begin{tabular}{|lcc|}
\hline $\begin{array}{l}\text { Source of } \\
\text { unlabelled }\end{array}$ DNA & $\begin{array}{c}\text { G+C } \\
\text { content } \\
(\mathbf{m o l} \%)\end{array}$ & $\begin{array}{c}\text { Relatedness to } \\
{ }^{3} \text { H-labelled DNA } \\
\text { from G-16.1 }\end{array}$ \\
\hline G-16.1 & (\%) \\
G-2.5 & $61 \cdot 0$ & 100 \\
G-17.1 & $61 \cdot 5$ & 90 \\
H-30.2 & $62 \cdot 5$ & 93 \\
H. salina ATCC $49509^{\mathrm{T}}$ & $62 \cdot 9$ & 90 \\
H. halophila CCM $3662^{\mathrm{T}}$ & $64 \cdot 2^{*}$ & 49 \\
H. elongata ATCC $33173^{\mathrm{T}}$ & $66 \cdot 7^{*}$ & 11 \\
\hline
\end{tabular}

${ }^{\star}$ Data from Arahal et al. (2002).
$49 \%$ with $H$. salina and $11 \%$ with $H$. halophila, indicating that this strain is genotypically distinct from the type strains of these species (Wayne et al., 1987).

Particularly remarkable is the extreme nutritional versatility presented by these novel isolates in comparison with their closest relatives. This metabolic difference constitutes a key differentiating property of this novel group of moderate halophiles. Other differential features are shown in Table 2. Overall, the phenotypic, genotypic and phylogenetic results suggest that isolates G-16.1 ${ }^{\mathrm{T}}$, G-2.5, G-17.1 and H-30.2 should be assigned to a novel species within the genus Halomonas. On the basis of the ability of these isolates to degrade different aromatic organic compounds, the name Halomonas organivorans sp. nov. is proposed.

\section{Description of Halomonas organivorans sp. nov.}

Halomonas organivorans (N.L. n. organum organic compound; L. v. vorare to eat, to consume; N.L. part. adj. organivorans devouring organic compounds).

Cells are motile, Gram-negative rods, $2 \cdot 0-3 \cdot 0 \times 1 \cdot 0$ $1 \cdot 2 \mu \mathrm{m}$. Colonies are cream, flat/slightly convex, opaque and raised with slightly irregular edges on SW-10 medium. Moderately halophilic, growing in a wide range $(1 \cdot 5-30 \%$, $\mathrm{w} / \mathrm{v}$ ) of salt concentrations, with optimum growth at $7 \cdot 5-10 \%(\mathrm{w} / \mathrm{v})$ salts. No growth in the absence of $\mathrm{NaCl}$. No other salt requirements have been determined. Growth occurs at $15-45^{\circ} \mathrm{C}$ (optimal temperature $37^{\circ} \mathrm{C}$ ) and at pH 6.0-10.0 (optimal pH 7.0). Strictly aerobic. Catalase is produced, aesculin is hydrolysed. Negative results in oxidase, indole, methyl red and Voges-Proskauer tests. Gelatin, casein, starch and DNA are not hydrolysed. As determined with the Biolog GN panel, the following compounds are utilized: glycogen, Tween 40 , Tween $80, \mathrm{~N}$ acetyl-D-glucosamine, D-arabitol, i-erythritol, D-fructose, D-galactose, $\alpha$-D-glucose, $m$-inositol, D-mannitol, Dmannose, D-psicose, L-rhamnose, D-sorbitol, sucrose, D-trehalose, methylpyruvate, monomethyl succinate, acetic acid, cis-aconitic acid, citric acid, D-galactonic acid lactone, D-galacturonic acid, D-glucuronic acid, D-gluconic acid, $\beta$-hydroxybutyric acid, $p$-hydroxyphenylacetic acid, $\alpha$-ketoglutaric acid, DL-lactic acid, malonic acid, D-saccharic acid, succinic acid, bromosuccinic acid, D-alanine, Lalanine, L-alanyl-glycine, L-asparagine, L-aspartic acid, Lglutamic acid, L-histidine, hydroxy-L-proline, L-leucine, L-proline, L-serine, L-threonine, urocanic acid, inosine, uridine, putrescine, 2-aminoethanol and glycerol. The following compounds are not utilized: $\alpha$-cyclodextrin, dextrin, $N$-acetyl-D-galactosamine, adonitol, L-arabinose, cellobiose, L-fucose, gentiobiose, $\alpha$-D-lactose, lactulose, maltose, D-melibiose, methyl $\beta$-D-glucoside, D-raffinose, turanose, xylitol, formic acid, D-glucosaminic acid, $\alpha$-hydroxybutyric acid, $\gamma$-hydroxybutyric acid, itaconic acid, $\alpha$-ketobutyric acid, $\alpha$-ketovaleric acid, propionic acid, quinic acid, sebacic acid, succinamic acid, glucuronamide, alaninamide, glycyl-L-aspartic acid, glycyl-Lglutamic acid, L-ornithine, L-phenylalanine, L-pyroglutamic 
acid, D-serine, DL-carnitine, $\gamma$-aminobutyric acid, thymidine, phenylethylamine, 2,3-butanediol, DL- $\alpha$-glycerol phosphate, D-glucose 1-phosphate and D-glucose 6-phosphate. The DNA G $+\mathrm{C}$ content ranges between $61 \cdot 0$ and $62 \cdot 9 \mathrm{~mol} \%$.

Isolated from saline soils. The type strain is $\mathrm{G}-16.1^{\mathrm{T}}$ $\left(=\right.$ CECT $\left.5995^{\mathrm{T}}=\mathrm{CCM} 7142^{\mathrm{T}}\right)$. The DNA G $+\mathrm{C}$ content of the type strain is $61.0 \mathrm{~mol} \%$. One important property of this strain is its ability to utilize various organic compounds (Table 1) considered as pollutants as sole sources of carbon and energy.

\section{Acknowledgements}

This work was supported by grants from the Spanish Ministerio de Ciencia y Tecnología (REN2003-01650 and BMC2003-1344), the Quality of Life and Management of Living Resources Programme of the European Commission (QLK3-CT-2002-01972) and Junta de Andalucía.

\section{References}

Arahal, D. R., Ludwig, W., Schleifer, K. H. \& Ventosa, A. (2002). Phylogeny of the family Halomonadaceae based on $23 \mathrm{~S}$ and $16 \mathrm{~S}$ rDNA sequence analyses. Int J Syst Evol Microbiol 52, 241-249.

Berendes, F., Gottschalk, C., Heine-Dobbernach, E., Moore, E. R. B. \& Tindall, B. J. (1996). Halomonas desiderata sp. nov., a new alkaliphilic, halotolerant and denitrifying bacterium isolated from a municipal sewage works. Syst Appl Microbiol 19, 158-167.

Cohen, G. N. \& Rickenberg, R. H. (1956). Concentration specifique reversible des amino acides chez E. coli. Ann Inst Pasteur (Paris) 91 , 693-720 (in French).

De Ley, J. \& Tijtgat, R. (1970). Evaluation of membrane filter methods for DNA-DNA hybridization. Antonie van Leeuwenhoek $\mathbf{3 6}$ 461-474.

Dobson, S. J. \& Franzmann, P. D. (1996). Unification of the genera Deleya (Baumann et al. 1983), Halomonas (Vreeland et al. 1980), and Halovibrio (Fendrich 1988) and the species Paracoccus halodenitrificans (Robinson and Gibbons 1952) into a single genus, Halomonas, and placement of the genus Zymobacter in the family Halomonadaceae. Int J Syst Bacteriol 46, 550-558.

Franzmann, P. D., Wehmeyer, U. \& Stackebrandt, E. (1988). Halomonadaceae fam. nov., a new family of the class Proteobacteria to accommodate the genera Halomonas and Deleya. Syst Appl Microbiol 11, 16-19.

Garcia, M. T., Ventosa, A., Ruiz-Berraquero, F. \& Kocur, M. (1987). Taxonomic study and amended description of Vibrio costicola. Int J Syst Bacteriol 37, 251-256.

Johnson, J. L. (1994). Similarity analysis of DNAs. In Methods for General and Molecular Bacteriology, pp. 655-681. Edited by P. Gerhardt, R. G. E. Murray, W. A. Wood \& N. R. Krieg. Washington, DC: American Society for Microbiology.

Kushner, D. J. \& Kamekura, M. (1988). Physiology of halophilic eubacteria. In Halophilic Bacteria, vol. I, pp. 109-140. Edited by F. Rodríguez-Valera. Boca Raton, FL: CRC Press.

Ludwig, W. \& Strunk, O. (1996). ARB - a software environment for sequence data. http://www.arb-home.de

Maltseva, O., McGowan, C., Fulthorpe, R. \& Oriel, P. (1996). Degradation of 2,4-dichlorophenoxyacetic acid by haloalkaliphilic bacteria. Microbiology 142, 1115-1122.
Margesin, R. \& Schinner, F. (2001). Biodegradation and bioremediation of hydrocarbons in extreme environments. Appl Microbiol Biotechnol 56, 650-663.

Marmur, J. (1961). A procedure for the isolation of deoxyribonucleic acid from micro-organisms. J Mol Biol 3, 208-218.

Marmur, J. \& Doty, P. (1962). Determination of the base composition of deoxyribonucleic acid from its thermal denaturation temperature. J Mol Biol 5, 109-118.

Mata, J. A., Martinez-Canovas, J., Quesada, E. \& Bejar, V. (2002). A detailed phenotypic characterisation of the type strains of Halomonas species. Syst Appl Microbiol 25, 360-375.

Mellado, E. \& Ventosa, A. (2003). Biotechnological potential of moderately and extremely halophilic microorganisms. In Microorganisms for Health Care, Food and Enzyme Production, pp. 233256. Edited by J. L. Barredo. Kerala, India: Research Signpost.

Mellado, E., Moore, E. R. B., Nieto, J. J. \& Ventosa, A. (1995). Phylogenetic inferences and taxonomic consequences of $16 \mathrm{~S}$ ribosomal DNA sequence comparison of Chromohalobacter marismortui, Volcaniella eurihalina, and Deleya salina and reclassification of $V$. eurihalina as Halomonas eurihalina comb. nov. Int J Syst Bacteriol 45, 712-716.

Mormile, M. R., Romine, M. F., García, M. T., Ventosa, A., Bailey, T. J. \& Peyton, B. M. (1999). Halomonas campisalis sp. nov., a denitrifying, moderately haloalkaliphilic bacterium. Syst Appl Microbiol 22, 551-558.

Muñoz, J. A., Perez-Esteban, B., Esteban, M., de la Escalera, S., Gomez, M. A., Martínez-Toledo, M. V. \& Gonzalez-Lopez, J. (2001). Growth of moderately halophilic bacteria isolated from sea water using phenol as the sole carbon source. Folia Microbiol (Praha) 46, 297-302.

Nieto, J. J. \& Vargas, C. (2002). Synthesis of osmoprotectants by moderately halophilic bacteria: genetic and applied aspects. In Recent Research Developments in Microbiology, vol. 6, part II, pp. 403-418. Edited by S. G. Pandalai. Trivandrum, India: Research Signpost.

Nieto, J. J., Vargas, C. \& Ventosa, A. (2000). Osmoprotection mechanisms in the moderately halophilic bacterium Halomonas elongata. In Recent Research Developments in Microbiology, vol. 4, part I, pp. 43-54. Edited by S. G. Pandalai. Trivandrum, India: Research Signpost.

Owen, R. J. \& Hill, L. R. (1979). The estimation of base compositions, base pairing and genome size of bacterial deoxyribonucleic acids. In Identification Methods for Microbiologists, 2nd edn, pp. 217-296. Edited by F. A. Skinner \& D. W. Lovelock. London: Academic Press.

Quesada, E., Ventosa, A., Ruiz-Berraquero, F. \& RamosCormenzana, A. (1984). Deleya halophila, a new species of moderately halophilic bacteria. Int J Syst Bacteriol 34, 287-292.

Romano, I., Nicolaus, B., Lama, L., Manca, M. C. \& Gambacorta, A. (1996). Characterization of a haloalkalophilic strictly aerobic bacterium, isolated from Pantelleria island. Syst Appl Microbiol 19, 326-333.

Saitou, N. \& Nei, M. (1987). The neighbor-joining method: a new method for reconstructing phylogenetic trees. Mol Biol Evol 4, 406-425.

Valderrama, M. J., Quesada, E., Bejar, V., Ventosa, A., Gutiérrez, M. C., Ruiz-Berraquero, F. \& Ramos-Cormenzana, A. (1991). Deleya salina sp. nov., a moderately halophilic gram-negative bacterium. Int $J$ Syst Bacteriol 41, 377-384.

Ventosa, A., Quesada, E., Rodríguez-Valera, F., Ruiz-Berraquero, F. \& Ramos-Cormenzana, A. (1982). Numerical taxonomy of moderately halophilic Gram-negative rods. J Gen Microbiol 128, 1959-1968.

Ventosa, A., Oren, A. \& Nieto, J. J. (1998). Biology of moderately halophilic aerobic bacteria. Microbiol Mol Biol Rev 62, 504-544. 
Vreeland, R. H., Litchfield, C. D., Martin, E. L. \& Elliot, E. (1980). Halomonas elongata, a new genus and species of extremely salt-tolerant bacteria. Int J Syst Bacteriol 30, 485-495.

Wayne, L. G., Brenner, D. J., Colwell, R. R. \& 9 other authors (1987). International Committee on Systematic Bacteriology. Report of the ad hoc committee on reconciliation of approaches to bacterial systematics. Int J Syst Bacteriol 37, 463-464.

Wilson, K. (1987). Preparation of genomic DNA from bacteria. In Current Protocols in Molecular Biology, pp. 2.4.1-2.4.2. Edited by F. M. Ausubel, R. Brent, R. E. Kingston, D. D. Moore, J. G. Seidman, J. A. Smith \& K. Struhl. New York: Wiley. 